\title{
A biogeographic survey of the southern Carnarvon Basin, Western Australia: background and methods
}

\author{
Allan H. Burbidge ${ }^{1}$, N.L. McKenzie ${ }^{1}$ and Mark S. Harvey ${ }^{2}$ \\ 1 Department of Conservation and Land Management, PO Box 51, \\ Wanneroo, Western Australia 6065, Australia \\ ${ }^{2}$ Department of Terrestrial Invertebrates, Western Australian Museum, \\ Francis Street, Perth, Western Australia 6000, Australia
}

\begin{abstract}
This paper describes the setting and aims of a multi-disciplinary study to sample the biodiversity of a $75000 \mathrm{~km}^{2}$ region of Western Australia (the southern Carnarvon Basin), and identify biophysical factors related to the observed patterns of plant and animal distributions. The study was designed to provide a quantitative biological basis for conservation planning and monitoring.
\end{abstract}

\section{INTRODUCTION}

Decisions on the management of Australian rangelands (e.g. Harrington et al., 1984; Stafford Smith et al., 1997) have been constrained by the lack of data on patterns in biodiversity over most of the Australian arid zone. Even the species inventories of most phylogenetic groups in our arid bio-regions are fragmentary. While quantitative surveys of range condition have been carried out over large areas of the pastoral zone in Western Australia in recent years (e.g. Payne et al., 1987; Pringle, 1991), most have focussed on a sub-set of plants and all have ignored indigenous animal taxa entirely, thereby providing only a biased first approximation to the patterns in biodiversity. The need to acquire such information for long term planning of rangeland management has led a number of authors to recommend that the conservation resources of the Australian arid zone be identified and measures taken to ensure that these values are conserved (e.g. Foran et al., 1990; James et al., 1995; Landsberg et al., 1997).

James et al. (1995) identified four key research themes relevant to the Australian arid zone: "(1) identification of spatial and temporal patterns of distribution of native biota; (2) quantification of the impacts of pastoralism on native biota; (3) identification of, and control of, potential nonnative pest species; and (4) development of methods and technologies to allow regional conservation planning". We contribute data under the first (inventory) theme and analyse these data to provide a basis for improved regional conservation planning. The existing conservation reserve network is highly biased in many parts of the Australian arid zone (Thackway and Cresswell, 1995). In particular, the major conservation reserves in the Carnarvon Basin are confined to its periphery and do not include examples of some prominent land surfaces (Burbidge and McKenzie, 1995; see also Figure 1). Although there was significant information available in the form of opportunistic data and surveys of restricted areas or relatively narrow taxonomic groups, there has been no satisfactory basis for planning a representative, yet cost-effective reserve system. We therefore set out to design and conduct a survey that would sample the main environments of the region, allow an interpretation of factors determining the patterns of plant and animal distributions in the study area, provide an explicit basis for designing a conservation reserve system according to CAR criteria (comprehensiveness, adequacy and representativeness; see, for example, Woinarski and Norton, 1993), and to commence the design of such a system.

Stafford Smith et al. (1997) have argued that while ecologists need to provide ecological understanding of arid lands, it is also important that they actively seek the integration of this understanding in the wider policy debate. We attempt to provide a much better understanding of the biogeography of one part of the Australian arid zone, and a beginning to the integration of such knowledge into the wider debate.

\section{THE STUDY AREA}

The Carnarvon Basin extends from near Cape Range in the Exmouth area, south to the Murchison River and inland to the Kennedy Range. It is one of the major sedimentary basins of Western Australia and has a geological history spanning much of the last 450 million years (Wyrwoll, Stoneman, Elliott and Sandercock, 2000). 


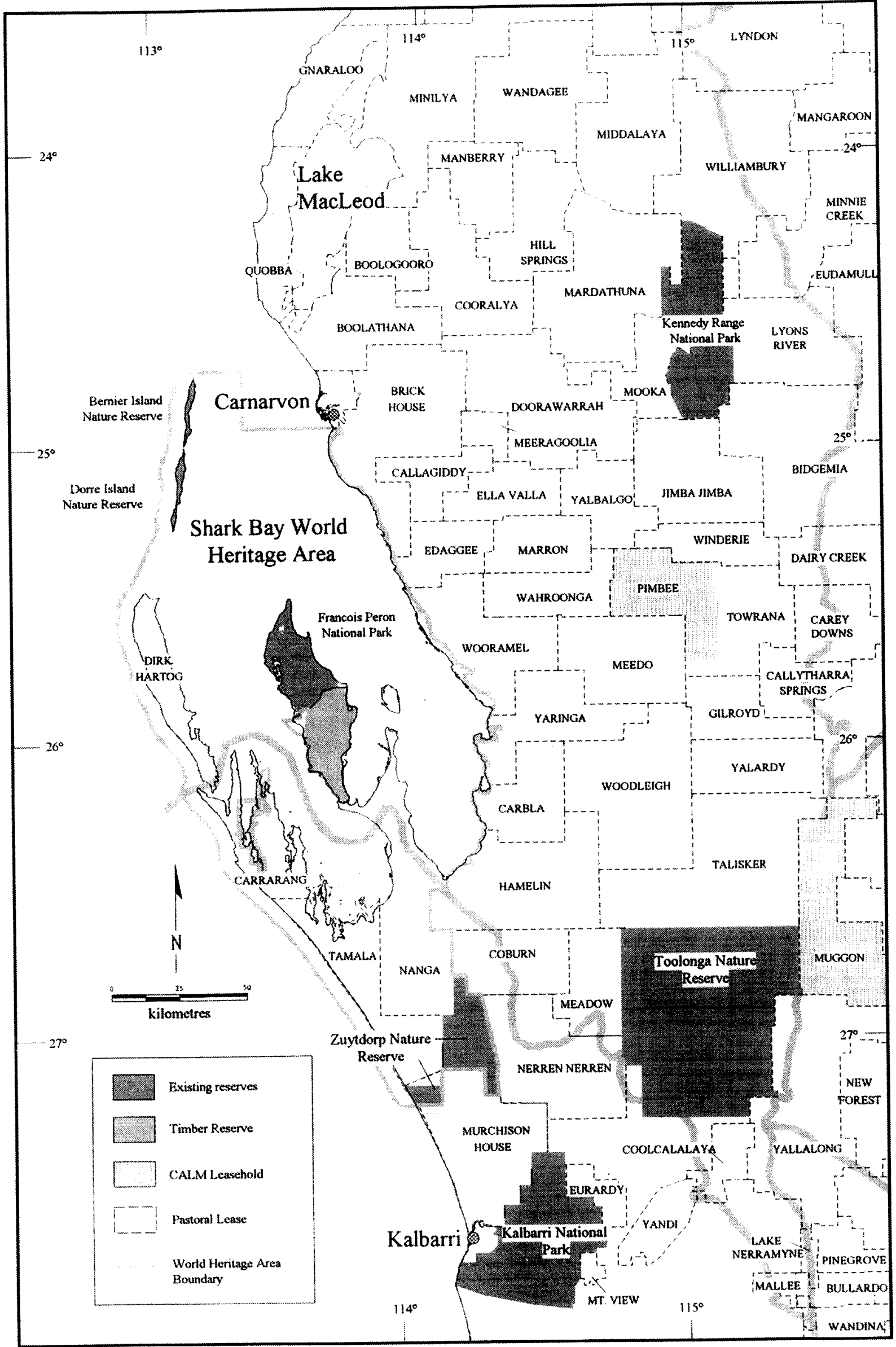

Figure 1 The extent of present day pastoral leases and major conservation reserves in the southern Carnarvon Basin. 
IBRA Regions

Thackway and Cresswell (1995) provide an Interim Biogeographic Regionalisation of Australia (IBRA) in which the country is divided into 80 regions based on various physical and biological attributes. Western Australia includes 26 of these regions, most of which are restricted to the state. The Carnarvon Region, located on the mid-west coast of Western Australia (Figure 2), extends from north of Exmouth Gulf south to Shark Bay. To the south lies the Geraldton Sandplains Region. The boundary between these two regions is also part of the boundary between the South-West Province and Eremaean Province of Beard (1990), i.e. the boundary between the arid and southern mesic parts of Western Australia. The present study was centred on this area.

Table 1 lists the variety of names for the biogeographic districts referred to in this and following papers. The Carnarvon Region (Thackway and Cresswell, 1995) has a similar northern and eastern boundary to the Carnarvon Basin (see Wyrwoll, Stoneman, Elliott and Sandercock, 2000). However, the Carnarvon Region extends south only to Shark Bay where it adjoins the Geraldton Sandplains Region [equivalent to Beard's (1980) Irwin Botanical District], which includes the southern edge of Shark Bay and the southern end of the Carnarvon Basin.

\section{Carnarvon Region}

The Carnarvon Region occupies the northern and central areas of the non-marine parts of the Carnarvon Basin. Because of its geographical position, the region is influenced by both the winter rainfall of the south-west and the summer rainfall of the north. It has an arid to semi-arid climate, with a mean annual rainfall as low as 200 millimetres in places. Severe droughts are a prominent element of the climate (see Wyrwoll, Courtney and Sandercock, 2000).

The Region is dominated by extensive, lowgradient, alluvial plains traversed by the Minilya, Gascoyne and Wooramel Rivers (Figure 2; Wyrwoll, Stoneman, Elliott and Sandercock, 2000). These rivers flow intermittently. Low, open woodlands of Acacia species, such as Snakewood (A. xiphophylla) and Bowgada (A. linophylla), over shrubs such as
Poverty Bush (Eremophila), cassias (Senna) and saltbush, occur on these plains (Beard 1990 and references therein). Shrubs and hummock grasses grow on the low sand ridges that are scattered across the plains. In northern parts, the plains grade into red sand dune fields, supporting spinifex and mulga communities that are reminiscent of Australia's red centre. In the south, near the boundary with the Geraldton Sandplains Region, the plains support Eucalyptus-Callitris woodlands on yellow sand dunes. Intermittently flooded claypans are common and, close to the coast, birridas (evaporite pans) occur in interdunal depressions. Low-lying areas, such as the birridas, the fringes of Lake MacLeod and the coastal flats, support rich samphire communities. In the east of the study area, erosional uplands such as the Kennedy Range provide a contrast to the surrounding plains.

Land-use in the area is predominantly for pastoral purposes, with significant areas on the margins being set aside for nature conservation.

\section{Geraldton Sandplains Region}

The Geraldton Sandplains Region extends from Shark Bay south to the vicinity of Jurien and Badgingarra at about latitude $30^{\circ}$ (Beard, 1990). The climate is dry warm Mediterranean, with cool wet winters and hot, dry summers. The region is dominated by heaths and scrub-heaths near the coast. Extensive areas of coastal limestone, partially mantled by pale yellow to grey sands, support low heaths with emergent thickets of Banksia and mallees, such as Illyarrie (Eucalyptus erythrocorys). A particularly impressive feature of the area to the south of Shark Bay is the Zuytdorp cliffs, which are topped with windblown, almost prostrate shrubland. Further inland, these are replaced by mallee, Banksia or Actinostrobus scrubs and heaths, with Acacia-Allocasuarina thickets still further inland. Small areas of Eucalyptus woodlands occur, mostly in the southern part of the region. The part of the region included in the present survey is mostly covered with sand, with some limestone outcropping very near the coast, and extends south to the Murchison River (Figure 2).

Much of the northern Geraldton Sandplains Region is used for pastoral purposes, with the remainder mostly being in conservation reserves;

Table 1 Comparison of the names used by Beard (1980, 1990) and Thackway and Cresswell (1995) for certain biogeographic entities referred to in the present study.

\begin{tabular}{lll}
\hline Beard, $\mathbf{1 9 8 0}$ & Beard, $\mathbf{1 9 9 0}$ & Thackway and Cresswell, 1995 \\
\hline Irwin Botanical District & Northern Sandplains & Geraldton Sandplains Region \\
Carnarvon Botanical District & Carnarvon Region & Carnarvon Region \\
Austin Botanical District & Murchison Region & Murchison Region \\
Ashburton Botanical District & Gascoyne Region & Gascoyne Region \\
\hline
\end{tabular}


there is some vacant Crown land north-east of Kalbarri National Park.

\section{Study Area Boundaries}

The study area for the current project extends north to the Minilya River, inland to the eastern boundary of the Carnarvon Basin and south to about the Murchison River (Figure 2). It includes the floristically and zoologically rich area around the boundary between the Geraldton Sandplains and Carnarvon Regions [the 'mulga-eucalypt line' of Serventy and Whittell (1967) and others], as well as Acacia woodlands and shrublands characteristic of the southern two thirds of the Carnarvon Region. It therefore includes the whole of the Shark Bay area but excludes most of the northern tropical end of the Carnarvon Region, which is dominated by hummock grassland.

\section{Why Southern Carnarvon Basin?}

We positioned our study area to straddle one of Western Australia's most important biogeographic boundaries, in an area known to have great faunistic and floristic complexity. This, it was hoped, would help provide a more meaningful understanding of the factors that determine the patterns of distribution of the plant and animal groups sampled in our study. We therefore sampled the woodlands, heaths and shrublands of the northern Geraldton Sandplains and southern Carnarvon Regions, as well as the arid zone communities of Acacia woodland and hummock grassland that characterise the Carnarvon Region. The area of the southern Carnarvon Basin as defined herein was about $7.5 \times 10^{6}$ hectares. We did not have the resources to sample the northern end of the Carnarvon Region.

An additional reason to extend the study area to the south was to include all the Shark Bay World Heritage Property (Anonymous, 1995).

\section{HISTORY OF EXPLORATION}

\section{Aboriginal Occupation}

Evidence of Aboriginal occupation at Shark Bay goes back at least 18000 years (Bowdler, 1990a). Cape Range, north of our study area but still within the Carnarvon Basin, was occupied by Aboriginal people over 30000 years ago and the range has a continuous history of occupation since that time (Morse, 1993). Presumably the remainder of the Carnarvon Basin has a similar history, at least along the river systems, but there is no archaeological evidence available to confirm this.

Seven tribes occurred in the southern Carnarvon Basin, occupying more or less non-overlapping parts of the region (Tindale, 1974). These people subsisted off wild plants and animals, although actual use is mostly not documented; in fact, very little is known of the traditional life and customs of the pre-European Aboriginal people of Shark Bay (Bowdler, 1990b). However, deposits at Cape Range (Morse, 1993) indicate that coastal inhabiting peoples gathered a range of food items from the marine environment, including crabs, gastropods, dugongs and turtles. On Peron Peninsula, archaeological evidence shows that macropods and Emu eggs have been used from Pleistocene times. Fish and marine invertebrates have also been important food sources for much of this time, but evidence for the use of dugongs and turtles is only available from the Holocene (Bowdler 1990a, 1995). Aboriginal peoples in the area probably used fire as a tool of land management, but the impact of their activities on the flora and fauna of the Carnarvon Basin are unknown. Clark (1992) provides a series of interviews with older members of the Yammatji people, who inhabited the Gascoyne region, but these are primarily a record of life on early pastoral properties, and little seems to be recorded of their traditional way of life.

\section{European Exploration and Settlement}

The first recorded landing by a European in Western Australia was at Cape Inscription, at the northern end of Dirk Hartog Island, where Captain Dirk Hartog landed in 1616 (Battye, 1915). He also mapped Dorre Island and the entrances to Shark Bay (named later by William Dampier). Hartog and several other early Dutch sailors (including Haevick Claeszoon van Hillegom, J. van Roosenbergh, Wollebrand Geleynzoon de Jongh and Antonie Caen) made only passing reference to any natural history observations they made. Near Bernier Island, Caen did make what appears to be the first recorded sighting of Black Swans by a European, although Willem de Vlamingh is known as the one who brought the bird to the attention of Europeans, following his observations on the Swan River (Serventy and Whittell, 1967).

On the other hand, William Dampier, who explored the Shark Bay islands in 1699 (Marchant, 1988; George, 1999), compiled some of the earliest botanical collections by Europeans in Australia (Finney, 1984). These are still preserved in the University Herbarium, Oxford. His illustrations of four birds he saw in the Shark Bay area (Rednecked Avocet, Pied Oystercatcher, Bridled Tern and Common Noddy) in his book Voyage to New Holland, are the earliest known illustrations of Australian birds (Whittell 1954). Dampier also described a macropod, presumably a Banded HareWallaby (Lagostrophus fasciatus) (Troughton, 1973). This was not the first reference to a macropod, the Dutch having made earlier references from Houtman's Abrolhos and Rottnest Island, but it does appear to be the first from north-western 


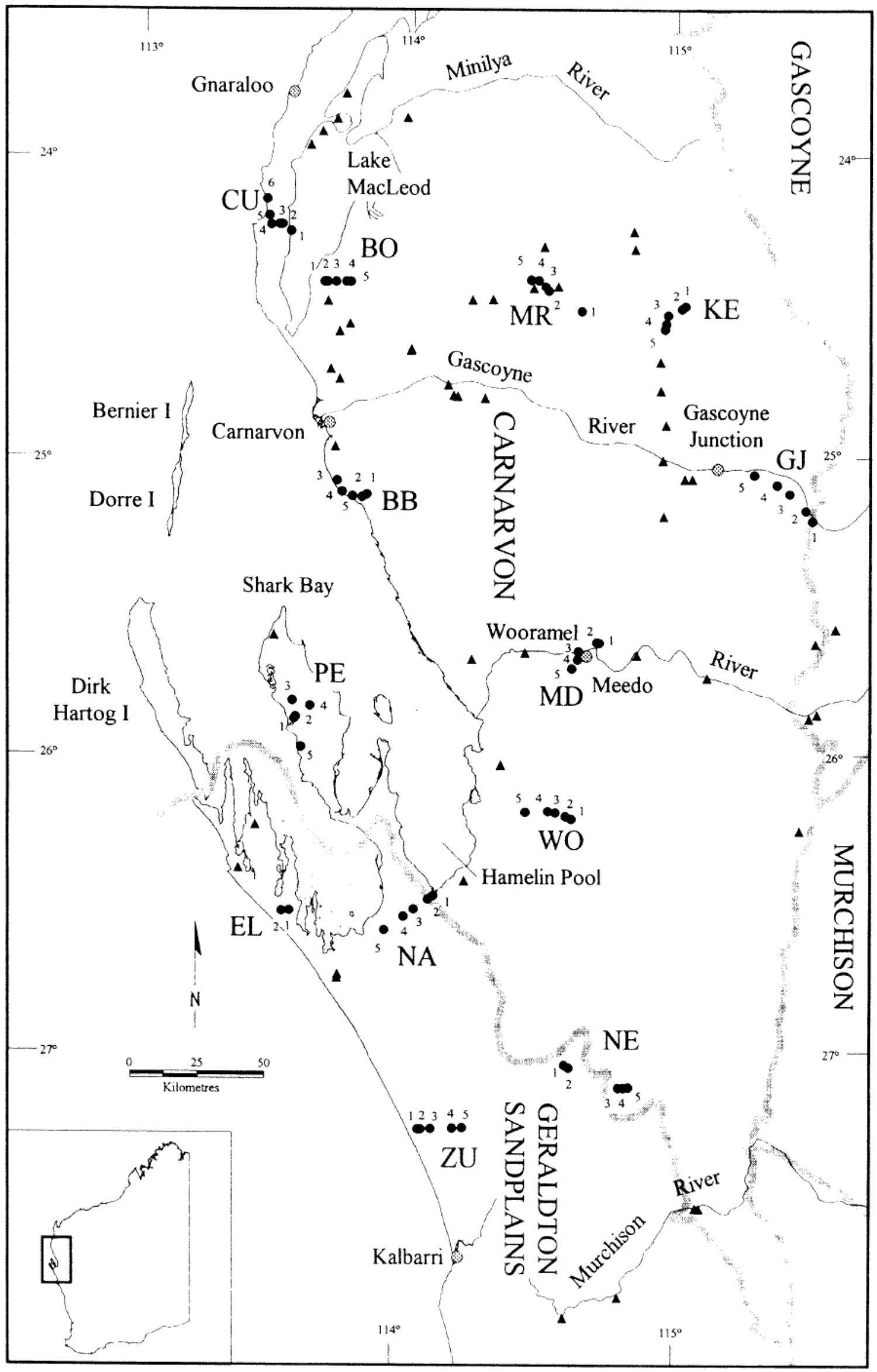

Figure 2 Location of sampling sites, place names mentioned in the text and major biogeographic boundaries (Thackway and Cresswell, 1995) in the southern Carnarvon Basin. Terrestrial sampling sites are marked as solid circles and aquatic sites as solid triangles. 
Australia and the Carnarvon Basin. Dampier also referred to other animals at Shark Bay, including lizards, "manatees" (Dugongs, Dugong dugon), fish and various marine invertebrates.

Important plant and animal collections (including terrestrial and marine collections) were also made by the French, during voyages in the early 1800 s [by Peron and Leschenault de La Tour with Baudin's expedition in 1801 and Quoy and Gaimard with Freycinet's expedition in 1818 (Marchant, 1998)], and by several English and German expeditions (sea and land) in the mid to late 1800 s. The German expedition led by Michaelsen and Hartmeyer in 1905 produced significant collections of terrestrial and marine invertebrates (Michaelsen and Hartmeyer, 1907-1930). Numerous studies have been made since the mid-1900s, adding considerably to our knowledge. Nevertheless, these have all been opportunistic collections or observations, or have been confined to a relatively narrow range of animals or plants.

Exploration of the interior for agricultural and development reasons began in 1839, when Captain George Grey discovered the Gascoyne River and explored the coast in the vicinity of the river and the present day Carnarvon, where he reported the presence of fertile soils (Battye, 1915). Francis Thomas Gregory explored the length of the Gascoyne River in 1858 and, on his return to Perth, reported that there were several tracts of well-watered land along the river that were admirably suited for pastoral purposes. Pastoral settlement followed soon after. C. von Bibra took up land near the Gascoyne in 1863 , quickly followed by others nearby and at Dirk Hartog Island and near Freycinet Harbour. These early attempts apparently failed; the first successful attempt in the area appears to have occurred when Aubrey Brown and John Monger took up land at the mouth of the Gascoyne River, Brown having overlanded 4000 sheep from York. In 1876 Brown established the pastoral property that later became known as 'Brickhouse' (Burnside, 1979). 'Boolathana', just north of the mouth of the Gascoyne River, was established by Charles Brockman in 1877. 'Lyons River', east of the Kennedy Range, was taken up before 1877 and 'Jimba Jimba', at the junction of the Gascoyne and Lyons Rivers, in 1878. Stations away from the coast or river frontage were established later; for example, 'Mardathuna' was established in 1902 (Battye, 1915; McDonald, 1991). An interesting account of station life in the 1880 s is provided by Carter (1987); a different perspective is provided by Clark (1992). The extent of present day pastoral leases is shown in Figure 2. Sheep numbers in the Carnarvon Basin peaked at over 1 million in the mid-1920s but dropped sharply to less than half this number by about 1940 . In the following 40 years numbers did not exceed about 730000 animals (Payne et al., 1987).
Other exploitative activities began in the 1840s (Battye, 1915; Cooper, 1997). Guano mining started in Shark Bay in 1847 and a small pearling industry was commenced in the 1860 s. Sandalwood cutting commenced on Peron c. 1860 and was being loaded onto sailing ships at Gladstone from the early 1870s. American and French whalers probably operated in the area from about 1803, and in the 1950s and 1960 s whaling stations were operating first from Point Cloates and later from Carnarvon. Fishing (for a variety of sea foods) has also been carried out over a long period (Cooper, 1997; Fry, 1988). Apart from fishing, none of these industries has persisted, but salt extraction now occurs at Useless Loop, Shark Bay.

\section{EXISTING KNOWLEDGE}

Existing knowledge of the physical and climatic environment and the forces and processes that have shaped the landscapes of the Carnarvon Basin is summarised in Wyrwoll, Courtney and Sandercock (2000) and Wyrwoll, Stoneman, Elliott and Sandercock (2000).

At the beginning of the survey, knowledge of the study area's plant and animal species was based on opportunistic collections made for various museums and herbaria (see above), particularly for the Western Australian Museum and Western Australian Herbarium. Some of these (e.g. Burbidge and George, 1978) have provided a good overview of particular areas, but there has been no previous systematic survey of the entire area.

A number of vertebrate pests occur in the study area, with the main ones being rabbits, goats, foxes and cats; their occurrence in this area is summarised by Payne et al. (1987). Amongst plant pests in the region, Buffel Grass (Cenchrus ciliaris) is known to be a serious environmental weed (Humphries et al., 1991; Griffin, 1993) although there seems to have been little done concerning documentation of its distribution or environmental effects in the study area or development of management options.

The Western Australian Conservation Through Reserves Committee (CTRC) provided recommendations on a reserve system for the Carnarvon Basin (and all other regions for the State) (e.g. CTRC, 1974). The recommendations were based on existing knowledge and constituted a valuable advance in reserve system design for the Carnarvon Basin. However, most recommendations concerned areas on the periphery of the region, with a number of major communities not included in the proposals.

The available data did not provide a basis from which to appraise future trends in biodiversity under the disturbance regimes (particularly grazing and introduced predators and other pests) that have been imposed following European settlement. 


\section{National Reserves System Cooperative Program}

The commitment of the Commonwealth Government, in cooperation with the States and Territories, to develop a comprehensive national system of parks and reserves, was outlined in the Prime Minister's December 1992 Statement on the Environment. Through this initiative the National Reserves System Cooperative Program (NRSCP) was established and administered by the Australian Nature Conservation Authority. The Program later became the National Reserve System Program of the Biodiversity Unit in Environment Australia. The aim of the NRSCP was to facilitate progress toward a national comprehensive, adequate and representative system of reserves to be established progressively by the year 2000 . The southern Carnarvon Basin survey was funded under the NRSCP as a cooperative project between the Commonwealth Government and the Government of the State of Western Australia as part of this commitment.

\section{THE SURVEY}

General aims of the survey have been outlined above. The underlying strategy used was a quadrat based survey in which data were collected as biophysical attributes measured at the same place in the same time frame, to enable us to investigate associations between species occurrence and environmental gradients (Austin et al., 1984; McKenzie et al., 1991; Margules and Austin, 1994; McKenzie, Halse and Gibson, 2000).

General arrangements for the survey are outlined below. Specific details are provided in individual papers.

\section{The Field Sampling Program}

It was agreed between the State and Commonwealth Governments that the survey would include sampling of vascular plants, aquatic invertebrates, at least one major terrestrial invertebrate group, reptiles, amphibians, birds and small mammals, together with an analysis of soil attributes or water chemistry at each sample site.

The sampling program was divided into three major phases:

- selection of sampling sites,

- first sampling: aquatic in winter 1994, terrestrial in spring 1994,

- second sampling: aquatic in summer 1994/95, terrestrial in autumn 1995.

Some additional sampling, to extend the geographic and temporal coverage, was done outside these periods (see below and relevant papers following).

Specifically, we aimed to:

- carry out the first systematic survey of vascular plants, aquatic invertebrates, terrestrial invertebrates, reptiles, amphibians, birds and small mammals in the Carnarvon Basin,

- collect voucher material for relevant museums and herbaria (particularly the Western Australian Museum and Western Australian Herbarium) for detailed taxonomic appraisal,

- investigate relationships between species occurrences and attributes of the study area's physical environment, to identify predictors of gradients in species composition across the study area,

- provide an overview of the status and distribution of species (both native and naturalised) and species assemblages,

- provide a quadrat-based benchmark, against which future changes in the status of the biota can be measured,

- provide a regional context for conserving the study area's biodiversity,

- provide recommendations for improving the design of the present conservation reserve system and

- provide recommendations for the conservation of priority species and species assemblages outside the existing conservation reserve system.

\section{Terrestrial Sites}

Preliminary selection of the general areas in which sampling sites would be established was done by N.L. McKenzie, A.H. Burbidge, G.J. Keighery, K.P. Aplin and M.S. Harvey and, based on an appraisal of existing knowledge, including vegetation mapping (Beard, 1975, 1976) and geological mapping (Denman and van de Graaff, 1982; Denman et al., 1985; Butcher et al., 1984; Hocking et al., 1982, 1985, 1987; van de Graaff $e t$ al., 1982). The preliminary selection was then refined following liaison with CALM regional staff (G. Leaman and $R$. Shephard). Actual sites were selected in the field by N.L. McKenzie, M.S. Harvey, G.J. Keighery and A.H. Burbidge between 7 April and 15 April 1994.

Sample sites were positioned throughout the geographical extent of the study area in a stratified random array, with quadrats in typical examples of each of the main surface stratigraphic units that characterise the study area. From two to six sites were clustered around each of 13 survey areas, herein referred to as 'campsites'. A total of 63 terrestrial sites were sampled. Details are described in the relevant chapters following, but in general terms, for the purposes of vertebrate sampling, each quadrat was $400 \times 400 \mathrm{~m}$, centred on the pit lines and a smaller $(30 \times 30 \mathrm{~m})$ quadrat used for sampling vascular plants. If there was obvious internal heterogeneity at a site, a second plant quadrat was 
established. Invertebrate pit lines were placed near the vertebrate lines.

Campsite codes (Figure 1 and other papers in this volume) are as follows: BB - Bush Bay; BO - Boolathana; CU - Cuvier; EL - Edel Land; GJ - Gascoyne Junction; KE - Kennedy Range; MD - Meedo; MR - Mardathuna; NA - Nanga; NE - Nerren Nerren; PE - Peron Peninsula; WO-Woodleigh; ZU - Zuytdorp.

All relevant pastoralists (who previously had been written to) were visited at the time of site selection. Site establishment (digging pitfall traps) was conducted from 27 April to late May 1994. Some opportunistic data collection (e.g. occurrence of birds at sites) was conducted during the site selection and establishment periods. Initially, 61 sites were selected, but two additional sites were established on Edel Land (EL) when it became apparent from preliminary analyses that this area was under-sampled.

Invertebrate pits were installed in August 1994 and left open until August 1995.

Spring zoological sampling was conducted from 26 September to 19 October 1994. Personnel involved, and sites visited, are outlined in Table 2. Sites listed in Tables 2 and 3 were sampled for five days and five nights in each period. Sites at ED were sampled for birds by P. Stone in August 1995. These sites and 21 others were sampled for grounddwelling vertebrates by N.L. McKenzie, J.K. Rolfe and W. Muir in November 1995. Further sampling for ground-dwelling vertebrates was carried out on all but the Edel Land (EL) quadrats in March 1996 [see McKenzie, Rolfe, et al. (2000) for details].
Autumn zoological sampling was undertaken from 8 May to 3 June 1995 (Table 3).

Physical attributes were sampled by $\mathrm{K}-\mathrm{H}$. Wyrwoll and T. Stoneman (Wyrwoll, Stoneman, Elliott and Sandercock, 2000).

\section{Aquatic Sites}

Possible sampling sites were identified by Halse et al. (2000) from existing biological and geomorphic knowledge and field inspection during a reconnaissance survey early in 1994. Relevant pastoralists were also contacted at this time. Site selection was finalised at the time of first (winter) sampling (August 1994). The selected set of sites includes representatives of all common wetland types in the region. Where possible, sites were also sampled in summer (March 1995), but some did not contain water at this time. A total of 56 sites were sampled, representing 53 wetlands. Sampling focussed on aquatic invertebrates, waterbirds and vascular flora.

\section{Conditions at the Time of Sampling}

The study area has a rainfall regime showing high variability through time and high patchiness (Wyrwoll, Courtney and Sandercock, 2000). During the years 1994 and 1995, when most of our sampling was done, Carnarvon and Meedo had below average rainfall in 1994 and above average in 1995, Gascoyne Junction had above average rainfall both years, Hamelin Pool had below average rainfall both years and Gnaraloo (north of Quobba) had close to its average rainfall in both years (Table 4). At the terrestrial sites, the differences between

Table 2 Personnel, attributes sampled and sites visited during the spring zoological sampling in the Carnarvon-Irwin study area during 1994. $\mathrm{M}=$ mammals, $\mathrm{B}=$ birds, $\mathrm{R}=$ reptiles and amphibians, $\mathrm{I}=$ invertebrates.

\begin{tabular}{lll}
\hline Team & Personnel & Sites visited \\
\hline 1. & $\begin{array}{l}\text { N. Hall and P. Boglio (M), A.H. Burbidge (B), J.K. Rolfe (R), } \\
\text { A. Sampey (I), I. Cresswell (M,B,R,I) }\end{array}$ & BO, GJ, PE, ZU \\
2. & $\begin{array}{l}\text { N.L. McKenzie (M, R), R.E. Johnstone (B), W. Muir (R), } \\
\text { P.J.L. West (I), P. Stone (B) }\end{array}$ & CU, MR, MD, NA \\
3. & $\begin{array}{l}\text { A.A. Burbidge (M), P.J. Fuller (B), A. Desmond (R), M.S. Harvey and } \\
\text { J.M. Waldock (I) }\end{array}$ & BB, KE, WO, NE \\
\hline
\end{tabular}

Table 3 Personnel, attributes sampled and sites visited during the autumn zoological sampling in the CarnarvonIrwin study area during $1994 . \mathrm{M}=$ mammals, $\mathrm{B}=$ birds, $\mathrm{R}=$ reptiles and amphibians, $\mathrm{I}=$ invertebrates.

\begin{tabular}{lll}
\hline Team & Personnel & Sites visited \\
\hline 1. & $\begin{array}{l}\text { N. Hall and P. Boglio (M), A.H. Burbidge (B), J.K. Rolfe and M. Cowan (R), } \\
\text { A. Sampey (I) }\end{array}$ & EL, NA, MD, MR, CU \\
2. & $\begin{array}{l}\text { N.L. McKenzie (M, R), R.E. Johnstone and P. Stone (B), W. Muir and } \\
\text { L. Smith (R), P.J.L. West (I) }\end{array}$ & NE, WO, BB, KE \\
3. & $\begin{array}{l}\text { A.A. Burbidge/P. Boglio (M), P.J. Fuller (B), A. Desmond and } \\
\text { B. Maryan (R), M.S. Harvey and J.M. Waldock (I) }\end{array}$ & ZU, PE, BO, GJ
\end{tabular}


Table 4 Annual rainfall for 1994 and 1995, and longterm average annual rainfall for selected rainfall stations in the study area (data from Australian Bureau of Meteorology).

\begin{tabular}{lrrr}
\hline Station & \multicolumn{3}{c}{ Rainfall (mm) } \\
& $\mathbf{1 9 9 4}$ & $\mathbf{1 9 9 5}$ & average \\
\hline Carnarvon & 135 & 269 & 228 \\
Hamelin Pool & 134 & 109 & 207 \\
Gnaraloo & 200 & 233 & 230 \\
Meedo & 92 & 322 & 216 \\
Gascoyne Junction & 259 & 273 & 206 \\
\hline
\end{tabular}

the seasons were most marked at Meedo. At this site, sampling was difficult in spring 1994 due to the dry conditions following a period in which six of the previous eight months exhibited below average rainfall. In autumn 1995 animals were noticeably more abundant, and herbaceous growth much more obvious, following much above average rainfall in February, March and April.

As noted above, some wetlands contained water in both winter and summer, but some did not.

\section{Data storage and analysis}

Data were entered into standard PC databases from which presence-absence matrices for site by species were generated for analysis. We used the computer package PATN (Belbin, 1989, 1991), to detect patterns of species composition in the data matrices. In most papers herein, the following sequence was used. The association measure 'Twostep' (Belbin, 1980) was used to determine the quantitative relationship between each pair of species, to allow classification of species in terms of the sites at which they occurred. The 'Two-step' measure is robust for use in situations, such as the present one, where sites vary greatly in their levels of species richness (Austin and Belbin, 1982). The Czekanowski measure (Czekanowski, 1932) was used to compare the quadrats according to their species composition. This procedure is appropriate for ecological presence-absence data and is robust to variations in species abundance patterns and sampling efficiencies (Faith et al., 1987; Belbin, 1991). For both measures of association, a modified version of unweighted pair group arithmetic averaging (UPGMA - Sneath and Sokal, 1973; Belbin, 1991) heirarchial clustering strategy was used, with the clustering parameter (Beta) set to -0.1. Two-way tables were constructed from the classifications of sites and species, in order to facilitate interpretation of both classifications. For particular groups, this analysis path was extended in various ways, as described in the relevant papers; extensions included the use of group statistics and generalised linear modelling to relate biological patterns to attributes of the physical environments on the sampling sites.
All sites were photographed, and scanned images are available on CD in selected libraries, including the libraries of the Western Australian Department of Conservation and Land Management, the Western Australian Museum and Environment Australia (Canberra).

\section{Funding}

Commonwealth funding for this project (\$438 366) was provided under the National Reserves System Co-operative Program of the Australian Nature Conservation Agency (later the National Reserve System Program of the Biodiversity Unit in Environment Australia). State Government funding for the survey included more than $\$ 100000$ provided through the Western Australian Museum and more than $\$ 300000$ provided through CALM. The State Government contribution included existing infrastructure and permanent staff.

\section{ACKNOWLEDGEMENTS}

First, we would like to thank all those land managers who gave us permission to work on the lands under their care: Lockie McTaggart (Bidgemia), Bob Bettini (Boolathana), Paul Burt (Brickhouse), Dudley Maslin (Mardathuna), Jamie Dempster (Meedo), J. F. Sears (Nanga), Harold Crawford (Nerren Nerren), Mike Meecham (Quobba), Mick Clausen (Woodleigh), David Smith (Dampier Salt Ltd, Lake MacLeod Division), Bruce and Carolin May (Yaringa), T.L. Kempton (Yalardy), D.P. and R.M. Steadman (Wooramel), B.R. and L.M. Brown (Tamala), Noce Pty Ltd (Talisker), Frank Jasper Pty Ltd (Mt View), R.J. and L.M. Lefroy (Mooka), J.M. and N. Thom (Minilya), G.M.H. and V.F. Baston (Jimba Jimba), J.R.W.S. and J.A. Hopkinson (Hill Springs), Brian Wake (Hamelin), Hakko Sunbay Pty Ltd (Gnaraloo), Mungullah Community Aboriginal Corp. (Gilroyd), Doorawarrah Pastoral Company Pty Ltd (Doorawarrah), Maslen Holdings Pty Ltd (Cooralya), J.S. and M.J. Stephens (Coolcalalaya), Clough Resources (Carrarang), R.J. and M.S. Rogers (Carey Downs), P.A.F. Kopke and E.M. Gooch (Carbla), Bob and Dawn Porter (Riverside).

We would also like to thank Ian Cresswell of Environment Australia's Reserve System Unit who not only assisted with the administration of the Commonwealth funding but also assisted in the field sampling program.

A number of CALM and WAM staff members assisted with various aspects of the survey. In particular, we thank Keiran McNamara for his role in negotiating with the Commonwealth concerning funding for this and related projects, and Greg Leeman, Kelly Gillen and their staff in CALM'S Midwest Region for assistance with local advice. Dr 
Ken Aplin (WAM) and Professor Sandra Bowdler (University of Western Australia) assisted with the location of background reference material.

Funding (see above) was provided by the Commonwealth through the National Reserves System Co-operative Program of the Australian Nature Conservation Agency (now Environment Australia), together with funds provided by the Western Australian Department of Conservation and Land Management and the Western Australian Museum.

\section{REFERENCES}

Anonymous (1995). Australia's World Heritage. Dept. of the Environment, Sport and Territories, Canberra.

Austin, M.P. and Belbin, L. (1982). A new approach to the species classification problem in floristic analysis. Australian Journal of Ecology 7: 75-89.

Austin, M.P., Cunningham, R.B. and Fleming, P.M. (1984). New approaches to direct gradient analysis using environmental scalars and statistical curvefitting procedures. Vegetatio 55: 11-27.

Battye, J.S. (Ed) (1915). The History of the North West of Australia embracing Kimberley, Gascoyne and Murchison Districts. V.K. Jones and Co., Perth.

Beard, J.S. (1975). The vegetation of the Shark Bay and Edel areas, Western Australia. Vegmap Publications, Perth.

Beard, J.S. (1976). Vegetation survey of Western Australia: Murchison. Explanatory notes to Sheet 6 . University of Western Australia Press, Perth.

Beard J.S. (1980). A new phytogeographic map of Western Australia. Western Australian Herbarium Research Notes 3: 37-58.

Beard J.S. (1990). Plant life of Western Australia. Kangaroo Press, N.S.W.

Belbin, L. (1980). TWOSTP: a program incorporating asymmetric comparisons that uses two steps to produce a dissimilarity matrix. CSIRO Division of Water and Land Resources Technical Memorandum $80 / 9$.

Belbin, L. (1989). Technical Reference, PATN Pattern Analysis Package. CSIRO Division of Wildlife and Ecology, Canberra.

Belbin, L. (1991). The analysis of pattern in bio-survey data. In C.R. Margules and M.P. Austin (eds) Nature Conservation: Cost Effective Biological Surveys and Data Analysis. 176-190, CSIRO, Melbourne.

Bowdler, S. (1990a). The Silver Dollar site, Shark Bay: an interim report. Australian Aboriginal Studies 1990 No. 2: 60-63.

Bowdler, S. (1990b). Before Dirk Hartog: prehistoric archaeological research in Shark Bay, Western Australia. Australian Archaeology 30: 46-57.

Bowdler, S. (1995). The excavation of two small rockshelters at Monkey Mia, Shark Bay, Western Australia. Australian Archaeology 40: 1-13.

Burbidge, A.A. and George, A.S. (1978). The flora and fauna of Dirk Hartog Island, Western Australia. Journal of the Royal Society of Western Australia 60: 71-90.
Burbidge, A.H. and McKenzie, N.L. (1995). Patterns in nature: the biodiversity of the Carnarvon Basin. Landscope 11(2): 15-20.

Burnside, D.G. (1979). The pastoral industry of the North-West Kimberley and Goldfields. In G.H. Burvill (ed), Agriculture in Western Australia. 150 years of Development and Achievement 1829-1979: 249-262. University of Western Australia Press, Nedlands, Western Australia.

Butcher, B.P., van de Graaff, W.J.E. and Hocking, R.M. (1984). Shark Bay - Edel, Western Australia. 1 : 250000 Geological Series Geological Survey of Western Australia, Perth.

Carter, T, (1987). No Sundays in the Bush: an English jackeroo in Western Australia, 1887-1889. Lothian, Melbourne.

Clark, B. (1992). Yammatji. Aboriginal Memories of the Gascoyne. Hesperian Press, Victoria Park, Western Australia.

Conservation Through Reserves Committee (1974). Conservation Reserves in Western Australia. Report of the Conservation Through Reserves Committee to the Environmental Protection Authority 1974. Western Australian Environmental Protection Authority, Perth.

Cooper, R. (1997). Shark Bay Legends. L.J. Cogan, Geraldton and Rawlhouse Publishing, West Perth.

Czekanowski, J. (1932). Coefficient of racial likeness, und durchschmittliche differenz. Anthropologischer Anzeiger 9: 227-249.

Denman, P.D. and van de Graaff, W.J.E. (1982). Quobba, Western Australia. 1:250000 Geological Series. Geological Survey of Western Australia. Perth.

Denman, P.D., Hocking, R.M., Moore, P.S., Williams, I.R. and van de Graaff, W.J.E. (1985). Wooramel, Western Australia. 1:250000 Geological Series. Geological Survey of Western Australia. Perth.

Faith, D.P., Minchin, P.R. and Belbin, L. (1987). Compositional dissimilarity as a robust measure of ecological distance. Vegetatio 69: 57-68.

Finney, C.M. (1984). To Sail Beyond the Sunset. Natural History in Australia 1699-1829. Rigby, Adelaide.

Foran, B.D., Friedel, M.H., MacLeod, N.D., StaffordSmith, D.M. and Wilson, A.D. (1990). A Policy for the Future of Australia's Rangelands. CSIRO Division of Wildlife and Ecology, Canberra.

Fry, G.W. (1988). Shark Bay Days. Hesperian Press, Victoria Park, Western Australia.

George, A. (1999). William Dampier in New Holland. Bloomings Books, Hawthorn, Victoria.

Griffin, G.F. (1993). The spread of Buffel Grass in inland Australia: land use conflicts. In Proceedings $10^{\text {th }}$ Australian Weeds Conference and $14^{\text {th }}$ Asian Pacific Weed Science Society Conference: 501-504. Weed Society of Queensland, Brisbane.

Halse, S.A., Shiel, R.J., Storey, A.W., Edward, D.H.D., Lansbury, I., Cale, D.J. and Harvey, M.S. (2000). Aquatic invertebrates and waterbirds of wetlands and rivers of the southern Carnarvon Basin, Western Australia. Records of the Western Australian Museum Supplement No. 61: 217-267.

Harrington, G.N., Wilson, A.D. and Young, M.D. (eds) 
(1984). Management of Australia's Rangelands. CSIRO, Melbourne.

Hocking, R.M., van de Graaff, W.J.E., Blockley, J.G. and Butcher, B.P. (1982). Ajana, Western Australia. $1: 250000$ Geological Series. Geological Survey of Western Australia, Perth.

Hocking, R.M., Williams, S.J., Moore, P.S., Denman, P.D., Lavaring, I.H. and van de Graaff, W.J.E. (1985). Kennedy Range, Western Australia. 1:250000 Geological Series. Geological Survey of Western Australia, Perth.

Hocking, R.M., Moors, H.T. and van de Graaff, W.J.E. (1987). Geology of the Carnarvon Basin Western Australia. Geological Survey of Western Australia Bulletin 133.

Humphries, S.E., Groves, R.H. and Mitchell, D.S. (1991). Plant invasions of Australian ecosystems. A status review and major directions. Kowari 2: 1- 134.

James, C.D., Landsberg, J. and Morton, S.R. (1995). Ecological functioning in arid Australia and research to assist conservation of biodiversity. Pacific Conservation Biology 2: 126-142.

Landsberg, J., James, C.D., Morton, S.R., Hobbs, T.J., Stol, J., Drew, A. and Tongway, H. (1997). The effects of artificial sources of water on rangeland biodiversity. Final report to the Biodiversity Convention and Strategy Section of the Biodiversity Group, Environment Australia. CSIRO Wildlife and Ecology and Environment Australia Biodiversity Group, Canberra.

McDonald, R. (1991). Winning the Gascoyne. Hesperian Press, Victoria Park, Western Australia.

McKenzie, N.L., Robinson, A.C. and Belbin, L. (1991). Biogeographic survey of the Nullarbor District, Australia. In C. F. Margules and M. P. Austin (eds) Nature Conservation: Cost Effective Biological Surveys and Data Analysis: 109-126, CSIRO, Melbourne.

McKenzie, N.L., Halse, S.A. and Gibson, N. (2000) A nature reserve system for the southern Carnarvon Basin, Western Australia. Records of the Western Australian Museum Supplement No. 61: 547-567.

McKenzie, N.L., Rolfe, J.K., Aplin, K., Cowan, M. and Smith, L.A. (2000). Herpetofauna of the southern Carnarvon Basin, Western Australia. Records of the Western Australian Museum Supplement No. 61: 335360.

Marchant, L.R. (1988). An Island unto Itself: William Dampier and New Holland. Hesperian Press, Victoria Park, Western Australia.

Marchant, L.R. (1998). France Australe. Scott Four Colour Print, Perth.

Margules, C.R. and Austin, M.P. (1994). Biological models for monitoring species decline. Philosophical Transactions of the Royal Society of London B 344: 69-75.

Michaelsen, W. and Hartmeyer, R. (eds) (1907-1930). Die Fauna Sudwest-Australiens. Ergebnisse der Hamburger sudwest-australischen Forschungsreise 1905. Vols 1-5. Gustav Fischer, Jena.
Morse, K. (1993). Who can see the sea? Prehistoric Aboriginal occupation of the Cape Range peninsula. In W.F. Humphreys (ed.), The Biogeography of Cape Range, Western Australia. Records of the Western Australian Museum Supplement No. 45: 227-242.

Payne, A.L., Curry, P.J. and Spencer, G.F. (1987). An inventory and condition survey of rangelands in the Carnarvon Basin, Western Australia. Western Australian Department of Agriculture Technical Bulletin No. 73.

Pringle, H.J.R. (1991). Rangeland survey in Western Australia - history, methodology and applications. Department of Agriculture Western Australia Miscellaneous Publication No. 22/91.

Serventy, D.L. and Whittell, H.M. (1967). Birds of Western Australia. Lamb Publications Pty Ltd, Perth.

Sneath, P.H.A. and Sokal, R.R. (1973). Numerical Taxonomy. The Principles and Practice of Numerical Classification. W.H. Freeman, San Francisco.

Stafford Smith, M., Morton, S. and Ash, A. (1997). On the future of pastoralism in Australia's rangelands. In N. Klomp and I. Lunt (eds), Frontiers in Ecology. Building the Links: 7-16. Elsevier, Oxford.

Thackway, R. and Cresswell, I.D. (1995). (eds) An Interim Biogeographic Regionalisation of Australia. Australian Nature Conservation Agency, Canberra.

Tindale, N.B. (1974). Aboriginal Tribes of Australia. Their Terrain, Environmental Controls, Distribution, Limits, and Proper Names. University of California Press, Berkeley.

Troughton, E. (1973). Furred Animals of Australia. Angus and Robertson, Sydney and London. (revised and abridged edition).

van de Graaff, W.J.E., Hocking, R.M. and Butcher, B.P. (1982). Yaringa, Western Australia. 1:250000 Geological Series. Geological Survey of Western Australia. Perth, Western Australia.

Whittell, H.M. (1954). The Literature of Australian Birds. A History and a Bibliography of Australian Ornithology. Paterson Brokensha, Perth.

Woinarski, J.C.Z. and Norton, T.W. (1993). Towards a national system of forest reserves: a discussion paper. Department of Environment, Sports and Territories, Canberra.

Wyrwoll, K.-H., Courtney, J., and Sandercock, P. (2000). The climatic environment of the Carnarvon Basin, Western Australia. Records of the Western Australian Museum Supplement No. 61: 13-27.

Wyrwoll, K.-H., Stoneman, T., Elliott, G. and Sandercock, P. (2000). The geo-ecological setting of the Carnarvon Basin, Western Australia: geology, geomorphology and soils of selected sites. Records of the Western Australian Museum Supplement No. 61: 29-75.

Manuscript received 26 March 1999; accepted 15 September 1999. 